\title{
Reputation as a Competitive Advantage in International Market Entry in the Pharmaceutical
}

\author{
Vargas-Hernández JG ${ }^{1 *}$ and Wong Dan $\mathrm{AT}^{2}$ \\ ${ }^{1}$ Universidad de Guadalajara Periférico Norte 799 Edif. G201-7, Los Belenes, C.P. 45100, Zapopan, Jalisco, México \\ ${ }^{2}$ Centro Universitario de Ciencias Económico Administrativas Universidad de Guadalajara, Mexico
}

\begin{abstract}
The present research attempts to analyze from a theoretical and methodological view of the competitive advantage that companies have to use the reputation as a generating tool of market value and this is a difficult intangible factor to imitate that facilitates the company to entre international markets. The largest pharmaceutical companies in the world and Mexico will be studied, from its inception and its market value. Finally it is concluded that the pharmaceutical industry has been characterized as one the most difficult markets to enter for their high entry barriers and reputational capital.
\end{abstract}

Keywords: Reputation; Pharmaceutical industry; Internationalization JEL: M160, D430, I11

\section{Introduction}

The pharmaceutical industry has been characterized as an industry with high barriers to entry, from the need to enter with heavy investments in capital to creating a high brand reputation, through the reputation of the country of origin or its organizational system. This paper aims to analyze two successful companies in the pharmaceutical field, Unipharma and Novartis, which will allow as empirical support for this research.

\section{Theoretical Framework: Corporate Reputation and Brand}

According to Noor therapeutic specialization, differentiation on competition and the ability to generate value in the pharmaceutical industry can create new market niches and countless future possibilities for companies to enter later in international markets [1]. Pharmaceutical companies have enjoyed for years the good image and reputation they have to the citizens, because they have seen how companies are engaged in the search for the cure of the great evils of health faced by the vast majority of the population [2]. This may be due to large investments made in the pharmaceutical services marketing, promoting his social and ethical responsibility. According to Gagnon and Lexchin big pharma in United States it has been more concerned to create a major brand to invest in research and development. It came to believe that several of these companies invested almost twice services in marketing, from sample drugs, trade television, royalties and doctors, among others, in research and development.

No doubt the brand that represents a company is paramount. Many large companies that have persisted for years have come to understand that the value of the company no longer depend exclusively on service or product offered, but it's up to intangibles that many competitors cannot imitate, or that this involves a very high cost of doing so (due to legal regulations). Because every day there is more competition, and a growing dynamic change in the economic environment, many companies have opted to develop and maintain intangible assets and capabilities difficult to imitate as a way to gain advantage in the market this is as a tool for obtaining a better financial performance, mainly for businesses that require high levels of capitalization and investment to remain on the market and especially to enter new international markets [3].

Since the nineties, many companies took on greatly important to create large industrial brands, which could encourage high consumption and maintain an edge over its rivals in the industry. According to a study by Booz, Allen and Hamilton, they showed that in the first five years, 2000 companies were listed on the stock exchange gave it a much greater importance to brand than five years ago. For example, it can be seen this evolution in the following Table 1.

The role of the brand has been important over time. Building the brand has been central to the good financial performance. In fact, since 2000, many companies have entered the stock market, which has been shown in many jobs that these companies have a higher value in stocks relative to their brand. In turn, each day more companies strive to improve their brand. Many of these companies succeed, and agree that the relationship brand-financial performance has a close connection [4].

While the brand may be only a small representation of an entire company, the brand of a product can create value to other products of the same company. Value-generating capacity with successful brands have a great impact on consumers, since that it can translate reputation as quality and consumer safety, and ensure it continues to be true during the life of the company. The brand can mean success or failure of a company, as it can improve the corporate reputation of the company in society. As it has mentioned the academic Javier Fernandez Aguado, the corporate reputation is an ongoing process of consolidating the prestige of an entity that manages to all its stakeholders and that this ultimately achieves a competitive advantage.

Pharmaceutical companies that have dedicated themselves to improve their image and reputation with consumers have focused on finding that specific brand that has an emotional bond with the consumer. One of the marketing strategies most popular is to make people believe that it is synonym for welfare, health or control. The generating capacity to create links with its consumers create value in the medium and long term due to the ability to remember through

*Corresponding author: Vargas-hernández JG, Universidad de Guadalajara Periférico Norte 799 Edif. G201-7, Los Belenes, C.P. 45100, Zapopan, Jalisco, México, Tel: +523337703340, Ext. 25685; E-mail: jvargas2006@gmail.com, jgvh0811@yahoo.com, josevargas@cucea.udg.mx

Received May 18, 2015; Accepted June 24, 2015; Published July 02, 2015

Citation: Vargas-Hernández JG, Wong Dan AT (2015) Reputation as a Competitive Advantage in International Market Entry in the Pharmaceutical. Int J Econ Manag Sci 4: 260. doi:10.4172/21626359.1000260

Copyright: (c) 2015 Vargas-Hernández JG, et al. This is an open-access article distributed under the terms of the Creative Commons Attribution License, which permits unrestricted use, distribution, and reproduction in any medium, provided the original author and source are credited. 
Citation: Vargas-Hernández JG, Wong Dan AT (2015) Reputation as a Competitive Advantage in International Market Entry in the Pharmaceutical. Int J Econ Manag Sci 4: 260. doi:10.4172/21626359.1000260

Page 2 of 4

\begin{tabular}{|c|c|c|c|c|}
\hline Rank & Company headquaters [website] & 2013 Rx sales (USD in min) & 2013 R\&D spend (USD in min) & 2013 Top selling Drugs (USD in min) \\
\hline 1 & $\begin{array}{c}\text { Novarties } \\
\text { Basel, Switzerland [Novarties.com] }\end{array}$ & $\$ 46,017$ & $\$ 9,360.30$ & $\begin{array}{l}\text { Gleevac [4693] } \\
\text { Diovan [3524] } \\
\text { Lucentis [2383] }\end{array}$ \\
\hline 2 & $\begin{array}{c}\text { Pfizer } \\
\text { Newyork, Newyork [Pfizer.com] }\end{array}$ & $\$ 45,011$ & $\$ 6,254$ & $\begin{array}{l}\text { Lyrica [4595] } \\
\text { Prevnar } 13 \text { [3974] } \\
\text { Enbrel [3774] }\end{array}$ \\
\hline 3 & $\begin{array}{c}\text { Roche } \\
\text { Basel, Switzerland [Roche.com] }\end{array}$ & $\$ 39,143$ & $\$ 8,293.50$ & $\begin{array}{l}\text { Rituxan [7503] } \\
\text { Avastin [6751] } \\
\text { Herceptin [6562] }\end{array}$ \\
\hline 4 & $\begin{array}{c}\text { Sanofi } \\
\text { Paris, France [Sanofi.com] }\end{array}$ & $\$ 37,701$ & $\$ 6,117.40$ & $\begin{array}{l}\text { Lantus [7592] } \\
\text { Plavix [2460] } \\
\text { Lovenox [2262] }\end{array}$ \\
\hline 5 & $\begin{array}{c}\text { Merck \& Co } \\
\text { White house station, New jersey } \\
{[\text { Merck.com] }}\end{array}$ & $\$ 37,519$ & $\$ 7,123$ & $\begin{array}{c}\text { Januvia [4004] } \\
\text { Zetia [2658] } \\
\text { Remicade [2271] }\end{array}$ \\
\hline 6 & $\begin{array}{c}\text { GlaxoSmithKline } \\
\text { Brentford, England [gsk.com] }\end{array}$ & $\$ 33,055$ & $\$ 5,041$ & $\begin{array}{l}\text { Seretide/Advair [8251] } \\
\quad \text { Pediarix [1349] } \\
\text { Avodart [1341] }\end{array}$ \\
\hline 7 & $\begin{array}{l}\text { Johnson and Johnson } \\
\text { New Brunswick, New jersey [jnj.com] }\end{array}$ & $\$ 26,475$ & $\$ 5,810$ & $\begin{array}{l}\text { Remicade [5334] } \\
\text { Zytiga [1698] } \\
\text { Prezista [1673] }\end{array}$ \\
\hline 8 & $\begin{array}{c}\text { Astra Zeneca } \\
\text { London, England [atsrazeneca.com] }\end{array}$ & $\$ 24,523$ & $\$ 4,269$ & $\begin{array}{l}\text { Crestor [5622] } \\
\text { Nexium [3872] } \\
\text { Symbicort [3483] }\end{array}$ \\
\hline 9 & $\begin{array}{c}\text { Eli Lilly } \\
\text { Indianapolies, Indiana [lilly.com] }\end{array}$ & $\$ 20,119$ & $\$ 5,316$ & $\begin{array}{l}\text { Cymbalta [5084] } \\
\text { Alimta [2703] } \\
\text { Humalog [2611] }\end{array}$ \\
\hline 10 & $\begin{array}{c}\text { AbbVie } \\
\text { North chicago, Illinois [abbive.com] }\end{array}$ & $\$ 18,790$ & $\$ 2,831$ & $\begin{array}{l}\text { Humira [10659] } \\
\text { AndroGel [1035] } \\
\text { Kaletra [962] }\end{array}$ \\
\hline
\end{tabular}

Table 1: Sales of the 10 Largest Pharmaceutical Companies.

association to positive attributes. According to Sinclair and Keller the brand creates value for retailers and for its rightful owner [5]. The assessment established to medium and long term is due to the accumulation of consumers over time, ensuring a flow of capital insured for the company, so that achieving stability and capitalization needed in case it seeks to extend its market or enter new market niches.

The value of the brand can be seen from two approaches. The first from a marketing perspective as mentioned previously and second from a financial perspective. How could be observes a brand from a financial perspective? The brand value from a financial perspective, variations can affect the selling prices by product, revenue from the sales number, or by the flow of each of the company through stock value [6]. This research focuses more on the financial perspective of the brand, because empirically it is assumed that the pharmaceutical industries are looking through the brand or corporate reputation to generate capital flows to ensure stability and this in turn leads to the company expansion into new markets. While it is always important to consider this point from a marketing view, since they are two features that are not excluded, on the contrary, both are necessary.

\section{Mechanism that Companies use to Focus their Attention to Corporate Reputation}

Pharmaceutical companies can focus their attention mostly running in marketing that allows improving the corporate image and their respective brands. This approach also can be called as intellectual capital, according to Edvinsson and Mallone. Companies require change their approach to the renewal and development capacity in the areas where they can provide value. Those areas should be focused on intangibles, as they are assets that can last more time than other physical assets, such as a patent for a more lasting brand under the law,

\begin{tabular}{|l|c|c|c|}
\hline & Mara (\%) & Otros Intangibles (\%) & Tangibles (\%) \\
\hline Suministros & 0 & 30 & 70 \\
\hline Industrial & 5 & 25 & 70 \\
\hline Farmacbubco & 10 & 50 & 40 \\
\hline Sector detallosta & 15 & 15 & 70 \\
\hline Info-tecnologia & 20 & 50 & 30 \\
\hline Automocien & 30 & 20 & 50 \\
\hline Servicsos financieros & 30 & 50 & 20 \\
\hline Alimentacten y bebidas & 55 & 5 & 40 \\
\hline Procknos as Sup & 70 & 5 & 25 \\
\hline
\end{tabular}

Fuente: Intarbrand.

Table 2: Comparative tangible and intangible brand

to a machine that has a time defined as useful and also depreciates in around the year. Unlike physical assets, intangible assets at least in the brand may be depreciated, but in turn it can be appreciated over time. So, it turns out to be profitable for companies, according to plan and life cycles, that they can guide their internal policies towards improving these types of goods.

The pharmaceutical industry has a very interesting feature in the market. They are the industries with more innovation and investment in technology and development. This through strong investments made for development and research, possibly for patents of new drugs-. According to Pharm Exec's Pharma50 (2014), the top 10 brands or pharmaceutical companies in 2014, together invested more than 54909.4 million in research and development, as shown in the following Table 2 below.

In the case of Novartis, a company of Swiss origin, it was the economic unit with higher pharmaceutical sales in 2013. Its investment in research and development was equivalent to $20 \%$ of its sales. The 
interesting thing about this case, Novartis in 2008 had lost large amounts of sales due to one of its US subsidiaries that contributed almost $40 \%$ of its profits; it had some unfortunate events that reduced profits. Among other causes, because it had delayed approval of a drug by the FDA, and the removal of other medications with losses of 600700 million dollars plus it had lost more than 1.6 million by the entry of generic drugs.

\section{Actions taken by the Corporate Novartis}

Like most companies, many chose to reduce their costs to stay in business, and above all have the same rate of profit. Novartis if any was similar case, which was a restructuring of downsizing, dismissals of 2000 employees in the United States as well as rationalization of therapeutic franchises [7]. Given the obvious decline in profits, as it is estimated that were almost 2.1 billion dollars, for the events in 2008, Novartis had to decide to fight these events through certain strategies:

A. Launch of 7 brands in 18 months,

B. Release of these products with the new restructuring and cost.

Given the evidence that would be a case of great challenge, directors of Novartis, decided to hire a team of marketing analysts, experts in sales and planning, focused on markets that were not covered in Europe previously, which already knew their niche market-as were the markets of hypertension and diabetes. Novartis quickly took control of the market to a huge pharmaceutical marketing strategy, managing to convince the strict European consumers. Through these 7 brands, they managed to recoup losses they had in the United States, and consolidated in some European countries, expanded to other countries, like the case of Spain, which eventually managed to meet the legislative standards required by that country. The marketing of a product before launch is vital to the survival of the company. In the pharmaceutical industry is no stranger to this issue, since clinical trials, identifying the types of patients, specific problems, and the differentiating ability of other brands and convincing the public, is vital applied marketing. This is the reason why Big Pharma spends a significant percentage of its income on marketing. Planning and investment required can lead investors or entrepreneurs interested in different market segments. This can be an important success factor of the pharmaceutical companies, and therefore responsible for promoting the corporate image of the product plays an important product to enter the market paper [7].

Consequently, after applying proper resource planning strategy is insurance company success to grasp those markets difficult to access, as it was mentioned, due to high restrictions in certain countries in pharmaceuticals, it is important that once broken that barrier to entry, can convince consumers of the efficiency and quality of the drug.

It can be seen from the above table that certain industries are highly relevant brand in the market. For pharmaceutical case, it only amounts to $10 \%, 50 \%$ in other intangibles and to $40 \%$ in tangibles. As is to avoid, it can be seen that industries that give more importance to the brand are luxury goods, financial services and food, although the latter, under personal opinion, it does not meet that much as some studies such as those conducted on Informality by the National Chamber of Commerce of Guadalajara. It was concluded that food and beverages the most important thing was the price, but may be deferred in the case of another country. The question as was discussed above, the reason why many of the companies have been engaged in investing in marketing may be due to the value of other intangibles are transferred indirectly to the brand.
It is possible, of course, because achieving to have a patent on the pharmaceutical industry to ensure that consumers will buy the product from the legal owner of the patent, but as with any type of good, there is some time constraints and lifetime. So that course of time, it has sought to invest in the promotion of the brand to create the emotional attachment, which had been previously analyzed, with the patient so that when the patent period is over, consumers at least cast doubt on the other brands that want to exploit the drug. Even if the brand is not as important as seen on the table, at least this is the first stage of the product as medium and long term, as it had already been discussed above, generate brand value.

Depending on the company and its products, as not all drugs are equal, is necessary to study which strategy is best for the company to use in the business's reputation approach, for example: A. Identify the company's reputation for product branding

\section{B. Identify the reputation of the brand through the corporation}

\section{Identify quality reputation by country of origin}

There may be other more relationships, but take these three basic for the industry that is being analyzed. In the internationalization process it can be inferred that must meet these three characteristics. Once consolidated the reputation of the brand and the corporation, companies must regularly tend to expand into new markets, which should cross borders through the export of goods or the mobility of the financial resources of the company to settle in another country to start a new production plant. The settlement process in a market already known, and stay for a period of time, allows the company to begin an accumulation process of financial capital, which allows also distributing profits among its shareholders, also begins to develop more research to future products in the case for pharmaceutical drugs. What reasons would have a company already established in the market to decide internationalize? According to executives Unipharma, Spanish company considered successful in the internationalization of its brand and image, the internalization process also allows new market access, improving the brand, company growth, higher profits and earnings.

The internationalization process has been of great interest to scholars,? from what time a company should internationalize? In the case of pharmaceuticals, due to its characteristics as a market of few competitors, entry barriers are very difficult to break, high capital investments, prestigious brand, among others, surpassing those characteristics; pharmaceutical companies can enter markets outside its country border. In the case of Unipharma, it went through this process to internationalize. His first steps before going abroad were to ask for help external consultants who were skilled in the process. The first development plan was based on identifying characteristics in emerging markets that have great potential, out of which will be made a priority selection according to geographical features. Unipharma by being of Spanish origin began analyzing near its border countries, such as France and Portugal that somehow some consumers had heard of the company [8].

Company strategies were adjusted according to the necessary diversification for the initial stage. Started using communication, advertising, location of suppliers and negotiation, and above all, to give confidence to consumers as well as corporate and product quality were indisputable.

One of the advantages of Unipharma was that in Europe knew that Spain had a strong pharmaceutical industry. After Unipharma begin promoted in other European countries, customers could identify the 
brand as good, by virtue of being Spanish. It was a process of successful and beneficial, in addition to assistance from public institutions to the rapidly expansion (Arian International, n.d.). The process of consolidation in the international market should get to look like in the local market, only that this time its competitors are multinationals. Also, it should be considered rigidities in regulations on patents and medicines, adapting different markets in different countries, the cumulative process capital to meet future challenges and other factors. Currently Unipharm is still in the process of adaptation and expansion.

In Mexican case, Genomma laboratories has been synonymous with success as a national brand and consolidation abroad, with about 60 brands that have been in high demand in Mexico.

It has presence in approximately in 15 countries around the world also created a division called Genomma Lab International, which is dedicated to the pharmaceutical marketing services, which has managed to keep promoting its brands on television, radio, internet, etc. Unlike other international companies put its own brands to enter foreign markets, Genomma Lab with financial consolidation managed to acquire several brands in the United States and Brazil to have an international presence. After, it acquired brands in Argentina and among other countries. This type of strategy has been repeated to achieve presence in the 15 countries mentioned above [9].

One of its most explosive was promoting strategies normal medicine called "first level" which caught the most commercial Mexican television and radio. Large inversions in marketing and brand building managed to get Genomma outside the top Mexican laboratories to venture into the international market.

\section{Conclusions}

Certainly, the process of internationalization is not an easy process for businesses, especially for the pharmaceutical industry, as noted above; these types of industries require high investments to enter the market to compete with the few players. In this market we have observed that corporate reputation is important for consumers, as customers will not consume something that is in question the quality, integrity, reputation or other factors influencing consumption as discussed in the same way, there are two ways of seeing the brand, including the generating capacity of financing. It is undoubtedly one of the features to consider a company to remain on the market. Giving an important role to brand can mean an improvement in the quality of the finances of the company, either because most trusted brand to supply and demand for financial assets as well as higher incentive product demand. With financial consolidation, it is then possible to analyze and study new niches wishing to enter international market in order to assess potential benefits that could have the company over its competitors. Consider the laws of each country, as it may be a factor preventing the company to develop in the best way. According to directives from Unipharma, pharmaceutical companies should focus more those emerging economies of the Third World, since the coverage of other companies have failed to do so. This has been due to a great large number of consumers, but difficulty in getting legislation, or cultural ignorance of those countries, and among others. But it will be very satisfied if a company can enter these types of market. To stay within an international market, it must have the same local process, the accumulation of capital for investment in research and development, which will create new products and patents that give competitive advantage. Achieving this, will have a more stable market guaranteeing the company growth and raising the brand value and company nationally and internationally. It is important to note that companies do not always commit all its resources to building the brand, should always be coordinated with other assets of the company, because due to over investment in some of the tangible or intangible assets put at risk the availability of resources to create value through another important element of the company.

\section{References}

1. Noor W (2014) AdvanstarCommunications, Inc.

2. Melé D (2006) Las Cinco Mayores Companias Farmacéuticas: Imagen Corporativa y Críticas en Responsabilidad Social. Cátedra Economía y Ética $1-12$.

3. Srivastava RK, Shervani TA, Fahey L (1997) Driving Share holder Value: The Role of Marketing in ReducingVulnerability and Volatility of Cash Flows. Journal of MarketFocused Management 2: 49-64.

4. Delgado Ballester ME (2011) La Creación de Marca como Estrategia Generadora de Valor. Colección Mediterráneo Económico: Nuevos enfoques del marketing y la creación de valor 433-446.

5. Sinclair RN, Keller KL (2008) A case forbrands as assets: Acquired and internallydeveloped. Journal of Brand Management 21: 286-302.

6. Exprúa J (2009) La Marca como generador de valor. Incae Business Review 70-72.

7. Bastien C, Serra T (2010) Novartis, Estrategia Comercial para el Éxito. IE Business School 1-34

8. Unipharma SA (2014) Unipharma, S.A.

9. Villafañe J (2001) La reputación corporativa como factor de liderazgo. Área abierta 1-6. 